\title{
THE EFFECT OF PSYCHOLOGY TRAITS ON STUDENTS SPEAKING ACHIEVEMENT
}

\author{
*Thresia Marisca \\ **Johan Sinulingga
}

\begin{abstract}
This study aims to find out the effect of Psychology Trait on Students' Speaking Achievement. The population of the study was the second year students in the academic year 2011 / 2012 at SMP HKBP Medan in two classes with a total of 64 students. Ten students were selected by using random sampling technique. The first group ( 5 students) was the extrovert group, while the second group (5 students) was the introvert group. The instruments of collecting data were questionnaire and oral test. The data were analyzed by using the Kruskal Wallis Test. The result of the analysis showed that the $\mathrm{H}$ $=\mathrm{X}^{2}$ value was higher than chi square table value $(4.81>3.94)$ at the level of significance 0.05 with a freedom degree of 10 . It means that there was a significance effect of Psychology Traits on Students' Achievement in Speaking.
\end{abstract}

Key Words: Pschology Traits, Speaking, Introvert, Extrovert.

\footnotetext{
* A graduate of English Language and Literature Department of UNIMED

** A lecturer of English Language and Literature Department of UNIMED
} 


\section{INTRODUCTION}

\section{Background of Study}

Language holds important role in every human's life. Communication is the way of human being to express his thought, feeling, and idea by using language. There are many various kinds of language in the world, such as Indonesian, Malay, Mandarin, France, Japanese, English, etc. Nowadays, English has become an International Language, although English is not the language with the largest number of native or 'first language speaker', it has become a lingua franca. A lingua franca can be defined as a language widely adopted for communication between two speakers whose native language are different from each other's and where one or both speakers are using it as a 'second' language.

For the various level of language learners-beginning, intermediate, and advanced, the four communication skills of listening, reading, writing, and speaking will be taught over and over. Whereas, the ultimate goal of all these activities is to lead the students toward the attainment of communicative competence the 'real' world.

As we know that the purpose of language is to communicate and one form of communication is the interaction between two or more speakers. This interaction is facilitated by what we known as the communicative competence.

Linguists then extended to communication the distinction that has been made in theoretical linguistics between (grammatical) competence and performance (Chomsky: 1965), and speaking as a part of the latter.

Speaking is the act, utterance, or discourse of one speaks. It also can be defined as an activity in giving and asking information as if dialoguing by two or more people.

As the person, which English is not our mother tongue; we sometimes find out that it was difficult thing to speak the language in our daily life. For that condition, there are various reasons indeed, and except from linguistic factors there are also psychological traits factors.

Concerned with the psychological factors, the writer start the idea from what it is called by personality.

Based on a famous psychologist; Carl Jung (1921) which believes that people's feelings fall in to two categories; extroverted and introverted. In that way, the writer encourages to know the influence of this factor to the speaking ability. Below are some statements which give the supporting details.

Brown (1990: 198) states "The most assertive and perhaps extroverted personality will usually dominate a conversation." It means that on doing speaking, the extroverts will be more often start the dialogue since he will not be satisfy to stay quiet.

Again, in his book, Teaching by Principles, Brown (1990:100) stated clearly that personality factors contribute in some way to the success of language learning. He explains the personality factors emerge as highly important aspects of carrying on discourse. In another way, the personality functioned mysterious ways in communication process also.

Barras (1995:6) also states, "Your style of writing reflects your whole personality, and the development of your ability to express yourself clearly and convincingly in speaking and writing is part of your continuing personal development." 
In one of Journal of psychology and sociology, Ramsay (1966) makes an interesting statement, "Extroverts make more sounds and have less silences." It is understanding that extroverts will more easily to make an answer to a question and the contrary, to tell something about since he will not comfortable in quiet circumstances.

Jung (1921) is the first expert who distinguishes two major attitudes or orientations of personality, the attitude of extraversion and the attitude of introversion. He explores that extraverted attitude orients the person toward the external, objective world; the introverted attitude orients the person toward the inner, subjective world. These two opposing attitudes are both present in the personality but ordinarily one of them is dominant and conscious while the other is subordinate and unconscious. If the ego is predominantly extraverted in its relation to the world, the personal unconscious will be introverted.

From the explanation above, obviously the extrovert and introvert have different way of delivering their feelings, thoughts and experiences. And these differences are an interesting thing to compare on the speaking ability.

\section{Research Questions}

Related to the background of the study that has been mentioned before, the problem of the study is formulated as the following: "Does psychology traits affect students' speaking achievement?"

\section{The Objective of the Study}

Based on the problem above, the objective of this is to find out if there is any effect of psychology traits in students' speaking achievement.

\section{The Scope of the Study}

This research deals with the effect of psychology traits in students' speaking achievement. There are some psychology traits; extrovert, introvert, neuroticism, agreeableness, etc.

Oral activities can be conducted inside and outside the classroom. Hok (1964) lists the following as forms of oral exercise: dialogues, games, improvisations, role play, discussion, conversation based on oral account, visual aids, or shared experiences such as field trips.

The writer considers that it is important for her to limit her study. This study is limited in the ability of extrovert and introvert students in making improvisations as one of speaking activities.

\section{The Significance of the Study}

The result of this research will be beneficial for:

1. English teachers who needs to know the effect of psychology traits in their students speaking.

2. The students with extroverted attitude and introverted attitude to increase their speaking performances 
3. Other researchers who are interested to explore and to do a research in other parts of personality or psychological factors in education field.

\section{Conceptual Framework}

Theories are needed to get a better understanding before conducting a research since some concepts can have wide spread meaning or blurred expression. So, any theory, which is related to this thesis, will be explained in the followings.

\section{Speaking}

Most people understand that speaking is the act to produce language for communication, one of the four basic skills, and we are very much like to speak. But, speaking is moreover, one of our most complex cognitive, linguistic and motor skills.

According to The New Grolier Webster International Dictionary (1975:684), "Speaking means as the act, utterance, or discourse of one who speaks," while as verb (speak) is to outer words or articulate sounds with the ordinary voice; to talk or exercise the faculty of speech; to make oral communication or mention as, to speak to someone various matters, to converse, as "They speak for hours on the phone."

Scott in Johnson (1981) defines speaking is typified as "an activity involving two or more people in which the participants are both hearers and speakers having to react what they hear and make their contributions at high speed". Each participant has an intention or set of intentions goals that he wants to achieve in the interaction. Each participant has to be able to interpret what is said to him, which he can not predict exactly either in terms of form or in terms of meaning, and reply with what language he has at his disposal a way that takes account of what just has been said and which reflects his own intentions at this point of interaction.

It is obvious that a speaker talks in order to have his message(s) conveyed, and in the time he also acts as a listener who must try to catch the meaning and give the appropriate responds so that there will be no misunderstandings and the communication then will be success. In other words we can say that in speaking there are two processes of taking and giving message(s) and two acts; as a speaker and a listener.

\section{Speaking Ability}

The term 'Speaking Ability' here means the ability to apply grammatical and discourse to communicate effectively in particular contexts for particular purposes, L.G. Alexander (1967).

L.G Alexander arranges the speaking ability within these purposes.

1. The ability to understand English dealing with everyday subjects and spoken at normal speed.

2. The ability to answer questions which require short and extended answers.

3. The ability to ask questions to elicit short or extended answers

4. The ability to use orally a large number of elementary sentences patterns.

5. The ability to reproduce orally substance of passage of English after having heard it several times and read it.

6. The ability to conduct a simple conversation on everyday subject 
(E.g. expressing preferences, polite, interchange, careers, travel, common experience, etc)

7. The ability to give a short talk (prepared or unprepared)

While Johnstone (1989) writes there are two kinds of language ability; basic interpersonal communication skills (BICS) and cognitive-academic language proficiency.

From the statements above, the researcher would only evaluate the sixth ability and the activity will be BICS. In other words, she only intends inn speaking ability to conduct a simple conversation or interview on everyday subject.

And in order to measure the speaking ability there are some elements that should have got attention: accent, grammar, vocabulary, fluency and, comprehension.

\section{Comprehension}

Based on The American Heritage Dictionary of the English Language (2003) states that comprehension is the act or fact of grasping the meaning, nature, or importance of something. It is also the act of understanding; understanding means the recognition of a general rule or principle or pattern.

This is more likely if there are several instances of the item that is being targeted for learning, so that the pattern or rule can be more easily perceived. It means that what the listener hears and understands from a speaker is to show his comprehension. In other way, the listener takes in the sounds uttered by a speaker and uses them to construct interpretation of what they think the speaker intended to convey. As a conclusion, comprehension is the ability to listen, to understand, and to speak intended.

\section{Psychology Traits}

In psychology, Trait theory is a major approach to the study of human personality. Trait theorists are primarily interested in the measurement of traits, which can be defined as habitual patterns of behavior, thought, and emotion. According to this perspective, traits are relatively stable over time, differ across individuals (e.g. some people are outgoing whereas others are shy), and influence behavior.

There is a nearly unlimited number of potential traits that could be used to describe personality. The statistical technique of factor analysis, however, has demonstrated that particular clusters of traits reliably correlate together. Hans Eysenck has suggested that personality is reducible to three major traits. Virtually all trait models, and even ancient Greek philosophy, include extraversion vs. introversion as a central dimension of human personality. Another prominent trait that is found in nearly all models is Neuroticism, or emotional instability.

The psychological maintains that the key to understanding the differences between the responses of one person and those of another lies in the personality.

According to one team of psychologists, personality is "those enduring characteristics of the person that are significant for interpersonal behavior (Goodstein and Lanyon, 1975)

Personality is defined as the total pattern of characteristics ways of thinking, feeling, and behaving that constitute the individual's distinctive method of relating to his or her environment. 
Hippocrates in the fifth and fourth centuries B.C. articulated one of the earliest and simplest ways to categorize people's personalities. He grouped all people into four groups: optimistic, grouchy, sluggish, or oral than melancholic in the introverts'. This difference is caused by some aspects in their daily life characteristics.

Carl Jung (1921) proposed another all-inclusive theory, based on the belief that people's feeling fall into two categories: extrovert and introvert (Dolande Jacobi, The Psychology of C.G Jung, rev, ed.). And probably the most widely known typology in introversion and extroversion is that of advanced by Jung

There are two basic personality or attitude types: an Extrovert and an Introvert. Most people utilize elements of both introversion and extroversion in their daily lives. However, there is usually a dominant personality trait that reflects how the person prefers to work or deal with the environment, especially when that person is under stress.

Let's start with taking a deeper look into the extrovert's personality traits. Most people believe an extrovert is someone who is outgoing and friendly. That, however, is not the true definition. An extrovert is a person who is energized by being around other people. This is the opposite of an introvert, whom is energized by being alone. An extrovert is also a person who may think in a way the centers around an object, being a task or a person. Extroverts enjoy social situations more than introverts. Extroverts seem to have more of an interest and concern with the external world. Extroverts are believed to make up 60 to 70 percent of society. Extrovert behavior seems to be the standard in American society, which means that other behavior is judged against the ways an extrovert would behave.

In order to understand the personality types will see the two processes, rational and irrational, which had been discussed by Jung (1921), below 


\begin{tabular}{|l|l|l|}
\hline $\begin{array}{l}\text { PROCESS } \\
\text { TYPE }\end{array}$ & \multicolumn{1}{|c|}{ EXTROVERTED } & \multicolumn{1}{|c|}{ INTROVERTED } \\
\hline Thinking Type & $\begin{array}{l}\text { This person utilizes logical } \\
\text { analysis in order to construct his } \\
\text { reality. He is concerned with } \\
\text { facts and their organization. }\end{array}$ & $\begin{array}{l}\text { He cognitive and } \\
\text { insular; his thinking is } \\
\text { highly subjective. }\end{array}$ \\
\hline Feeling Type & $\begin{array}{l}\text { This person feels in response } \\
\text { top some external circumstance; } \\
\text { he is able to establish } \\
\text { meaningful social relationships } \\
\text { and friendships with others; he } \\
\text { feels and acts according to the } \\
\text { demands placed upon him. }\end{array}$ & $\begin{array}{l}\text { Therson lives in his } \\
\text { own world of fantasies } \\
\text { and daydreams, he has his } \\
\text { own internal web of } \\
\text { emotions. }\end{array}$ \\
\hline Sensation Type & $\begin{array}{l}\text { This individual is oriented to } \\
\text { sensory impressions of a a } \\
\text { concrete nature; he is specific, a a } \\
\text { realist, and materialist. }\end{array}$ & $\begin{array}{l}\text { The impressionist } \\
\text { character who is aware of } \\
\text { the external world but } \\
\text { whose sensations are } \\
\text { collared by his subjective } \\
\text { state would fit this } \\
\text { personal category. }\end{array}$ \\
\hline Intuition Type & $\begin{array}{l}\text { Here external stimulation only } \\
\text { offers the individual for } \\
\text { understanding what is occurring } \\
\text { outside. The individual intuits } \\
\text { what ought to be done or } \\
\text { understood in the external } \\
\text { context. }\end{array}$ & $\begin{array}{l}\text { This person gives his } \\
\text { attention to imagery and } \\
\text { lives within his own world } \\
\text { of understandings He } \\
\text { maybe a religious } \\
\text { personality. }\end{array}$ \\
\hline
\end{tabular}

Then, based on Eysenck idea, Bischof (1970:497) summarizes that extroverts are related to Hippocrates' choleric and sanguine types, while introverts are melancholic and phlegmatic types. Further we find out the characteristics of extrovert are leadership, carefree, lively, easygoing, responsive, talkative, out going, sociable, touchy, restless, aggressive, excitable, impulsive, optimistic, and active. While introverts are the opposites, namely: moody, careful, thoughtful, peaceful, controlled, reliable, eventempered, quiet, unsociable, reserved, pessimistic, sober, rigid, anxious, and passive.

As the conclusion, we can say that an extrovert is an initial who disliked solitude and prefers the company of other people; while an introvert is a person who tends to be preoccupied with his own thoughts and activities and to avoid social contact.

\section{Hypothesis}

The hypothesis is a tentative answer to a problem in a research and still needs investigating in this case the writer's hypothesis is formulated as follow:

Ho: There is no effect of psychology traits in students' speaking achievement.

Ha: There is an effect of psychology traits in students' speaking achievement. 


\section{METHODOLOGY}

\section{Research Design}

This research was conducted in Ex Post Facto design. In Ex Post Facto design, the researcher is attempting to describe a causal relationship between an independent variable and a dependent variable. Kerlinger states (1973 : 379) that the Ex Post Facto research quite succinctly as systematic empirical inquiry in which the researcher does not have direct control of independent variables because their manifestations have already occurred or because they are not inherently not manipulation. Inferences About relations among variables are made, without direct intervention from concomitant variation of independent and dependent variables. The design utilized two different classes as the sample of the study. One of the classes was designed to be extrovert group and the other to be introvert group. This means that this study was intended to describe and to compare speaking ability of both extrovert and introvert students in speaking. There was used non parametric statistical.

\section{Population}

Best and Kahn (2002:13) point out that population is any group of individuals that have one or more characteristics in common that are of interest to the researcher. In this study, the population of this study was the second year of junior high school in SMP HKBP.

\section{Sample}

A sample is a small proportion of a population selected for observation and analysis (Best Kahn, 2002: 13).

The method which was applied to get the sample was random sampling, as Gay (1987) comments "even though there is no technique, not even random sampling can guarantee a representative sample but probability is higher for this procedure than any other".

The writer used random sampling by given a questionnaire to 100 students, then grouped 5 extroverts and 5 introvert students.

\section{The Instrument of Data Collection}

There are several ways of assessing specific variable of the students such as interview, observation, test, and questionnaire. In this research, the writer will use questionnaire to know the orientation of students' personality whether it is extrovert and introvert.

In testing the students' speaking achievement, it is usually impossible to predict precisely how students will respond, for communication allows and indeed encourages creativity on the part of the students. The type of test items suitable to test students' oral self-expression is the subjective test items. Such, test elicit free responses that must be scored subjectively.

\section{Validity and Reliability}


The validity and reliability determine how well a test is. These two factors had to be fulfilled by a test before it is used to derive valid data in research. The establishment and procedure of each aspect were discussed in the following parts: The concept of validity is referred to the next measured. Ary et al (2001: 195) says that validity is the extent to which it measures what it is supposed to measure and nothing else. In line with the concept of validity and the nature of writing regarded as a construct, the must valid instrument to measure the sample's ability to write is administering the writing test therefore it will fulfill the requirement of the construct validity. In other words, considering the nature of speaking and the concept of validity, construct validity was applied.

Reliability refers to the consistency of the measurement. According to Ary et al 2001: 206) reliability is the measurement of the degree to which a test gives consistency result when it is given on different occasion or different people. It means that a test is given on different occasion or different people. A test is given to different people to measure the same thing. To obtain the reliability, the writer used inter-rater reliability that could be computed by using Pearson's Product Moment Formula:

$$
\begin{aligned}
& r=\frac{N\left(\sum_{x y}\right)-\left(\sum_{x}\right)\left(\sum_{y}\right)}{\sqrt{\left\{N\left(\sum x^{2}\right)-\left(\sum x\right)^{2}\right\}\left\{N\left(\sum y^{2}\right)-\left(\sum y\right)^{2}\right\}}} \\
& \text { Where }: \mathrm{r} \quad \text { : The Reliability of the Test } \\
& \mathrm{N} \text { : The number of the Test } \\
& \Sigma \mathrm{x} \quad \text { : Total score of rater } 1 \\
& \Sigma y \quad \text { : Total score of rater } 2
\end{aligned}
$$

According to Best (2002), the reliability of the test could be categorized as follows:

$\begin{array}{ll}0.0-0.20 & \text { The reliability is very low } \\ 0.21-0.40 & \text { The reliability is low } \\ 0.41-0.60 & \text { The reliability is fair } \\ 0.81-0.80 & \text { The reliability is high } \\ 0.81-\text { above } & \text { The reliability is very high }\end{array}$

\section{Data Analysis}

The data required from the test has been conducted and the result will be analyzed in this chapter. The data were collected by given the students the questionnaires, from the result, the students divided into two groups. They are extrovert and introvert students.

\section{RESULTS \& DISCUSSION}

\section{Extrovert Speaking Achievement}

In classifying the speaking ability of extrovert students, a set of category, which is developed from the category proposed by FSI oral proficiency ratings used. The result of the classification is shown in the following table.

The category of extrovert speaking achievement is: 

$67-82$
is high achievement
$50-66$
is average achievement
$33-49$
is fair achievement
$16-32$
is poor achievement

The achievement of Extrovert Students

\begin{tabular}{|l|l|l|}
\hline $\begin{array}{c}\text { No. } \\
\text { Sample }\end{array}$ & $\begin{array}{c}\text { Extrovert } \\
\text { Score }\end{array}$ & Score \\
\hline 1 & 73 & High \\
\hline 2 & 71 & High \\
\hline 3 & 70 & High \\
\hline 4 & 60 & Average \\
\hline 5 & 57 & Average \\
\hline
\end{tabular}

It is clear for us that extrovert students are on the behalf of two upper classification with the scores varied between 57 up to 82, and as you can see in appendix II, they are generally marked to have foreign accent with occasional mispronunciations only. Their grammar only in the occasional errors and still can be understood. The choice of words sometime inaccurate but adequate to discuss special interests. Their speech is occasionally hesitant, but they can understand quite well.

\section{Introvert Speaking Achievement}

In classifying the speaking achievement of introvert students, the same set of category as the one used for extrovert students is used.

The following are the scores of the introvert students in doing the interview:

The achievement of Introvert Students

\begin{tabular}{|l|l|l|}
\hline $\begin{array}{c}\text { No. } \\
\text { Sample }\end{array}$ & $\begin{array}{c}\text { Introvert } \\
\text { Score }\end{array}$ & \multicolumn{1}{|c|}{ Level } \\
\hline 1 & 61 & Average \\
\hline 2 & 50 & Average \\
\hline 3 & 46 & Fair \\
\hline 4 & 44 & Fair \\
\hline 5 & 44 & Fair \\
\hline
\end{tabular}

From the table above, we get that generally, there are two classifications of the introvert level that are average and fair. The writer also notes here that in doing 
speaking, most of introverts have a very heavy accent and require frequent repetition. Their grammars are also uncontrolled and causing occasional misunderstanding while the limitations of their vocabulary prevent discussion of some common topics. The sentences may be left uncompleted and the speech is frequently hesitant. They can understand with some considerable repetition and rephrasing.

\section{Analyzing the data by using Kruskal Wallis Test Formula}

$$
H=\frac{12}{N(N+1)} \sum_{j=1}^{k}\left[\frac{\left(\sum R_{j}\right)^{2}}{n_{j}}\right]-3(N+1)
$$

$$
\begin{aligned}
\text { Where: } & \mathrm{N}=10 \\
\mathrm{n}=5 & \Sigma \mathrm{R} 1=38 \\
\mathrm{R} 2=17 & \frac{12}{N(N+1)}\left[\frac{\left(\sum R\right)^{2}}{n}\right]-3(N+1) \\
= & \frac{12}{10(10+1)}\left[\frac{(38)^{2}}{5}+\frac{(17)^{2}}{5}\right]-3(10+1) \\
= & \frac{12}{110}\left[\frac{1444}{5}+\frac{289}{5}\right]-33 \\
= & \frac{12}{110}\left[\frac{1733}{5}\right]-33 \\
= & \frac{20796}{550}-33 \\
= & 37,81-33 \\
= & 4,81
\end{aligned}
$$

\section{Testing Hypothesis}

The basis for testing hypothesis is as following:

$\mathrm{Ha}$ is accepted if the $\mathrm{H}$ observed $>$ Chi square-table. In this research the calculation of the score by using H-test for the degree of freedom (df) 10 at the level of significance, 0.05 that the critical value is 0.394 .

The result of computing the H-test showed that the H-observed value is higher than the Chi Square table or it can be seen as follows :I

H-obs $>$ Chi Square table $(\alpha=0.05)$ which df 10

$4.81>3.94(\alpha=0.05)$ which df 10

So based on the calculation, it can be said that there is a significant effect between the extrovert and introvert students on speaking. Thus, it can be said that the psychology traits significantly affects students' speaking achievement and the hypothesis saying there is significant effect of psychology traits on students' speaking achievement is accepted.

\section{CONCLUSION AND SUGGESTIONS}




\section{Conclusion}

1. More than a half of the extrovert students have high speaking ability, and the rest have the average, while the introvert students have fair ability and average ability.

2. The hypothesis (Ha) is accepted. It means that there is a significant difference in speaking ability between extrovert and introvert students.

3. Extrovert students have better speaking ability than the introvert students.

\section{Suggestions}

Based on the conclusion above, it would be better to offer suggestions:

1. Since most of extrovert students have different abilities in speaking with introvert students, it is advisable that the teacher guided the introvert students to perform their abilities in real situation so that they can achieve the same ability with the extrovert.

2. It is suggested that the students should be active and have more courage in doing the technique learning process. The teacher should attempt to encourage the students to improve their ability in speaking.

3. If the teacher applies speaking drills, she or he must directly give a hand to the students while they are doing it. The teacher task might become more difficult since he must improve not only their speaking but also their accent, grammar, vocabulary, fluency, and (listening) comprehension. Then, at every day class, the teacher should give them the chances to enhance their speaking ability.

4. To make introvert student able to speak as good as the extrovert, the teacher could make such as learner groups (speaking club) or make them into pairs of extrovert and introvert students. The introverts should not be all in the same group.

5. The teacher should learn more about techniques of teaching pronunciation. Pronunciation drills may be given in the form of recordings, or in the text, such as : sound-bracketing drills, minimal-pair drills, oral reading, listen-and-repeat drills, and songs. 


\section{REFERENCES}

Alexander,L.G.1967. Fluency in English. London: Longman.

Ary, D. et al. 2002. Introduction to Research in Education (2nd Ed.). Singapore: Wardswirth.

Barras, R. 1995. Students Must Write. New York: Routledge.

Best, J.W., \& Kahn, V.J. 2002. Research in Education (7th Ed.). New Delhi: Prentice Hall.

Bischof, L.J. 1970. Interpreting Personality Theories. New York: Harper\&Row.

Brown, H.D. 1990. Teaching by Principles. New Jersey: Prentice- Hall.

Brown, H.D. 2000. Principles of Language Learning and Teaching (4th Ed.). London: Longman Group.

Clark, H., \& Clark, E. 1977. Psychology and Language: An Introduction to Psycholinguistics. New York: Harcourt Brace Jovanovich.

Fulcher, G. 2003. Testing Second Language Speaking. Essex: Pearson Education Limited. 
Harmer, J. 2001. The Practice of English Language Teaching. Essex: Pearson Education Limited

Johnson, K., \& Morrow, K. 1981. Communication in the Classroom. London: Longman.

Johnstone, R. 1989. Communicative Interaction: a Guide for Language Teachers. London: Center for Information on Language Teaching and Research.

Jung, C.J. 1921. Psychologischen Typen (R. Verlag, Trans.). Zurich: H.G. Baynes.

Kroth, J. 1973.Counseling Psychology and Guidance: An Overview in Outline. Illinois: Charles C. Thomas.

Levelt, W. 1993. Speaking from Intention to Articulation. London: Massachusetts Institute of Technology.

Meister, D. 1985. Behavioral Analysis and Measurement Methods. Toronto: John Willey \& Sons.

Nunan, D. 1999. Second Language Teaching and Learning. Massachusetts: Heinle and Heinle.

Robinett, B.W. 1967. Teaching English to Speakers of Other Languages: Substance and Technique. Minneapolis: University of Minnesota Press.

Wells, G. 1981. Learning through Interaction: The Study of Language Development. New York: Cambridge University Press. 